\title{
Structural and Kinetic Studies in Propene Oxidation over Sb Oxide Dispersed on $\mathrm{TiO}_{2}$
}

\author{
Takehiko Ono,* Masaru Kiryu,* Masaharu Komiyama, $\dagger$ \\ AND ROBERT L. KUCZKOWSKI \\ *Department of Applied Chemistry, University of Osaka Prefecture, Sakai, Osaka 591, Japan, †Department \\ of Chemistry, Faculty of Liberal Arts and Education, Yamanashi University, Kofu, Yamanashi 400, Japan, \\ and $\ddagger$ Department of Chemistry, University of Michigan, Ann Arbor, Michigan 48109
}

Received February 13, 1990; revised August 20, 1990

\begin{abstract}
Antimony oxide dispersed on $\mathrm{TiO}_{2}$ was characterized using FTIR, Raman, and Auger spectroscopies as well as XRD. They indicate that the electronic environment about $\mathrm{Sb}$ is perturbed at low concentration suggesting that the structure of $\mathrm{Sb}$ oxide on $\mathrm{TiO}_{2}$ is somewhat distorted as compared to $\mathrm{Sb}_{6} \mathrm{O}_{13}$. The oxidation of labeled propene such as $\mathrm{CH}_{2}=\mathrm{CH}-\mathrm{CD}_{3},{ }^{13} \mathrm{CH}_{2}=\mathrm{CH}-\mathrm{CH}_{3}$, and cis$\mathrm{CHD}=\mathrm{CD}-\mathrm{CH}_{3}$ was examined on $\mathrm{Sb}_{6} \mathrm{O}_{13}$ and $\mathrm{Sb}-\mathrm{Ti}$ oxide catalysts. The results indicate that the first hydrogen abstraction is rate determining and that there is little or no isotope effect in the second hydrogen abstraction over $\mathrm{Sb}$ and $\mathrm{Sb}-\mathrm{Ti}$ oxide catalysts. The oxidation kinetics was discussed on the basis of a modified redox mechanism. The reduction step was promoted by a factor of ca. 50 over $\mathrm{Sb}$ oxide dispersed on $\mathrm{TiO}_{2}$ as compared to that on unsupported $\mathrm{Sb}_{6} \mathrm{O}_{13}$. Rate promotion was mainly attributed to the increase in the amount of active sites for the reduction step. $\mathcal{O} 1991$ Academic Press, Ine.
\end{abstract}

\section{INTRODUCTION}

Several mixed oxides containing Sb oxide are active catalysts for the partial oxidation and ammoxidation of olefins $(1,2)$. Regarding U-Sb oxide catalysts, Grasselli et al. (3) have proposed that $\mathrm{Sb}^{3+}-\mathrm{O}-\mathrm{Sb}^{5+}$ and $\mathrm{Sb}^{5+}-\mathrm{O}-\mathrm{Sb}^{5+}$ moieties are responsible for $\pi$-allyl formation and oxygen insertion in acrolein formation, respectively. Volta $e t$ al. (4) have proposed that the surface $\mathrm{Sb}^{3+}-\mathrm{Sb}^{5+}$ couples produced on $\mathrm{SnO}_{2}$ should be responsible for partial oxidation activity. Recently it has been proposed that the rutile structure oxides play an important role in the promotion of $\mathrm{Sb}$ oxide for the oxidation and ammoxidation of olefins over $\mathrm{Sb}-\mathrm{Sn}$ and $\mathrm{Sb}-\mathrm{Fe}$ oxide systems (2).

We have previously reported that there is an isotope effect in the first hydrogen abstraction and little or no isotope effect in the second hydrogen abstraction for the oxidation of propene over $\mathrm{Sb}-\mathrm{Sn}$ oxide catalysts $(5,6)$. Kinetic features on this catalyst have indicated that the promotion of the oxidation reaction can be attributed to an increase in the reduction step due to the presence of Sn ions.

$\mathrm{TiO}_{2}$ has been widely used as a support for both metal (7) and metal oxide (8) catalysts. The oxidation activity as well as structure of $\mathrm{V}$ oxide are strongly affected by the $\mathrm{TiO}_{2}$ support (8). One of the authors has also reported that the Mo oxide and $\mathrm{V}$ oxide highly dispersed on $\mathrm{TiO}_{2}(9)$ and $\mathrm{ZrO}_{2}(10)$ have higher activities in propene oxidation than crystalline $\mathrm{MoO}_{3}$ or $\mathrm{V}_{2} \mathrm{O}_{5}$. The promoter action was attributed to the presence of polymolybdate or polyvanadate species and the rate increase was attributed to an acceleration of the reduction step in the redox mechanism.

In this paper the activity and selectivity for propene oxidation to acrolein over $\mathrm{Sb}$ oxide dispersed on $\mathrm{TiO}_{2}$ were studied in much greater detail. The oxidation of labeled propene using $\mathrm{CH}_{2}=\mathrm{CH}-\mathrm{CD}_{3}$, cis$\mathrm{CHD}=\mathrm{CD}-\mathrm{CH}_{3}$, and ${ }^{13} \mathrm{CH}_{2}=\mathrm{CH}-\mathrm{CH}_{3}$ 
TABLE 1

Properties of the Catalysts

\begin{tabular}{llcr}
\hline $\begin{array}{c}\text { Catalyst } \\
(\mathrm{Sb} \text { at.\% })^{a}\end{array}$ & \multicolumn{1}{c}{$\begin{array}{c}\text { Phase } \\
\text { identified } \\
\text { by XRD }\end{array}$} & $\begin{array}{c}\text { Specific BET } \\
\text { surface area } \\
\left(\mathbf{m}^{2} \mathrm{~g}^{-1}\right)\end{array}$ & $\begin{array}{c}\text { Crystalline } \\
\% \text { of } \mathrm{Sb}_{6} \mathrm{O}_{13}\end{array}$ \\
\hline $\mathrm{TiO}_{2}{ }^{b}$ & $\begin{array}{c}\text { Anatase }(70 \%) \\
+ \text { rutile }(30 \%)\end{array}$ & 40 & 0 \\
$\mathrm{Sb}(5.5)-\mathrm{Ti}-\mathrm{O}$ & $\mathrm{TiO}_{2}$ & 35 & 15 \\
$\mathrm{Sb}(18)-\mathrm{Ti}-\mathrm{O}$ & $\mathrm{TiO}_{2}, \mathrm{Sb}_{6} \mathrm{O}_{13}$ & 33 & 84 \\
$\mathrm{Sb}(55)-\mathrm{Ti}-\mathrm{O}$ & $\mathrm{TiO}_{2}, \mathrm{Sb}_{6} \mathrm{O}_{13}$ & 35 & 100 \\
$\mathrm{Sb}(100)$ & $\mathrm{Sb}_{6} \mathrm{O}_{13}$ & 28 & \\
\hline
\end{tabular}

${ }^{a}$ Antimony loading, expressed as the atomic ratio $100 \mathrm{Sb} /(\mathrm{Sb}+\mathrm{Ti})$.

${ }^{b}$ Heated at $500^{\circ} \mathrm{C}$ for $8 \mathrm{hr}$ prior to catalyst preparation.

was investigated. The oxidation kinetics was discussed on the basis of a modified redox mechanism. The structure of Sb oxide on $\mathrm{TiO}_{2}$ was examined by means of XRD, FTIR, Raman, and Auger spectroscopy. The correlation between the structure of $\mathrm{Sb}$ oxide on $\mathrm{TiO}_{2}$ and the catalytic activity is discussed.

\section{EXPERIMENTAL}

Catalyst preparation. $\mathrm{Sb}(5.5,18$, and 55 atom\%)-Ti oxide catalysts were prepared as follows: $\mathrm{SbCl}_{5}$ was added into aqueous slurries containing desired quantities of $\mathrm{TiO}_{2}$ (Anatase: P-25, Degussa Co. Ltd.). The slurries were precipitated with ammonia solution and the resulting precipitates and slurries were filtered, dried, and heated at $450^{\circ} \mathrm{C}$. The catalysts used are listed in Table 1. As described below, $\mathrm{Sb}_{6} \mathrm{O}_{13}\left(\mathrm{Sb}^{3+}\right.$ $\mathrm{Sb}^{5+}=1 / 2$ ) was formed during preparation in spite of the use of $\mathrm{SbCl}_{5}\left(\mathrm{Sb}^{5+}\right)$.

Procedure and apparatus. The catalytic oxidation of propene was carried out in a closed circulation system (ca. 300 or 1000 $\mathrm{cm}^{3}$ in volume). The reaction products such as acrolein, $\mathrm{CO}_{2}$, and $\mathrm{CO}$ were analyzed by gas chromatography. The reactants $\mathrm{CH}_{2}$ $=\mathrm{CH}-\mathrm{CD}_{3} \quad(99 \%)$, cis- $\mathrm{CHD}=\mathrm{CD}-\mathrm{CH}_{3}$ (96.7\%), and ${ }^{13} \mathrm{CH}_{2}=\mathrm{CH}-\mathrm{CH}_{3}(99 \%)$ were obtained from MSD Canada, Ltd. $\mathrm{CH}_{2}=$ $\mathrm{CH}-\mathrm{CH}_{3}$ and $\mathrm{O}_{2}$ were obtained from regular commercial cylinders (99\%).
Microwave spectroscopy was used to determine the relative amounts of the isotopic acrolein products using a Hewlett-Packard $8460 \mathrm{~A}$ spectrometer (located at Univ. of Michigan). The $4_{04}-3_{03}, 4_{14}-3_{13}$, and $4_{13}-3_{12}$ transitions were mainly used. The procedure is described elsewhere (6, $11,12,13)$. This was not a sufficiently large set of transitions to obtain very high precision for the samples containing 3-4 isotopic species, but the precision in the isotopic ratios $( \pm 5 \%$ to $\pm 10 \%)$ in Tables 3-5 is sufficient to provide useful insights on the reaction processes.

$\mathrm{X}$-ray diffraction patterns of the catalysts were obtained on a Rigaku Denki RAD-rA diffractometer using $\mathrm{CuK} \alpha$ radiation. The goniometer stepper motor system and the signal were interfaced with a versatile data acquisition system. Using a step scanning method a small amount of crystalline phase is detectable. IR spectra were recorded on a Shimadzu FTIR 4000 spectrometer (located at Kobe University). The sample was prepared by mixing $\mathrm{KBr}$ and $\mathrm{Sb}-\mathrm{Ti}-\mathrm{O}$ oxides (ca. $1 \mathrm{wt} \%$ ). The Raman spectra were recorded using a JASCO NR-1000 laser Raman spectrometer. An Argon ion laser was tuned to the $514.5 \mathrm{~nm}$ line for excitation. The $\mathrm{X}$-ray-excited Auger spectra of the catalysts were recorded on a Shimazdu ESCA 750 spectrometer (located at Tohoku University) using $\mathrm{Mg} K \alpha$ radiation. 
TABLE 2

Characterization of the Catalysts

\begin{tabular}{|c|c|c|c|}
\hline $\begin{array}{c}\text { Catalyst } \\
\text { (Sb, at.\%) }\end{array}$ & $\begin{array}{c}\text { Noncrystalline } \\
\text { Sb oxide } \\
\left(\mu \mathrm{mol} \mathrm{m}^{-2}-\mathrm{TiO}_{2}\right)\end{array}$ & $\begin{array}{l}\text { IR spectra } \\
\text { of } \mathrm{Sb} \text { oxide } \\
\left(\mathrm{cm}^{-1}\right)\end{array}$ & $\begin{array}{c}\text { Auger } \mathrm{Sb} \\
M_{4} \mathbf{N}_{4,5} \mathbf{N}_{4,5} \\
\text { peaks }(\mathrm{eV})\end{array}$ \\
\hline $\mathrm{Sb}(5.5)-\mathrm{Ti}-\mathrm{O}$ & 2.7 & $900-890$ & 460.0 \\
\hline $\mathrm{Sb}(18)-\mathrm{Ti}-\mathrm{O}$ & 9.8 & $\begin{array}{c}895-870 \\
720\end{array}$ & 459.6 \\
\hline $\mathrm{Sb}(55)-\mathrm{Ti}-\mathrm{O}$ & 10 & 870,770 & 459.6 \\
\hline $\mathrm{Sb}_{6} \mathrm{O}_{13}$ & & $\begin{array}{c}870-850 \\
760,560\end{array}$ & 459.6 \\
\hline
\end{tabular}

\section{RESULTS AND DISCUSSION}

Characterization of $S b-T i-O$ catalysts. XRD patterns of the $\mathrm{Sb}(5.5)-\mathrm{Ti}-\mathrm{O}$ catalyst showed only the lines due to $\mathrm{TiO}_{2}$ (anatase + rutile). The $\mathrm{Sb}(18)$ and $\mathrm{Sb}(55)-\mathrm{Ti}-\mathrm{O}$ showed lines due to $\mathrm{Sb}_{6} \mathrm{O}_{13}$ (ASTM 21-51) and $\mathrm{TiO}_{2}$. The amount of crystalline $\mathrm{Sb}_{6} \mathrm{O}_{13}$ in these catalysts was estimated by a comparison of the XRD intensities of $\mathrm{Sb}_{6} \mathrm{O}_{13}$ for a physical mixture of $\mathrm{Sb}_{6} \mathrm{O}_{13}$ and $\mathrm{TiO}_{2}$ and the catalysts. After the amounts of crystalline $\mathrm{Sb}_{6} \mathrm{O}_{13}$ were estimated (Table 1), the percentages of noncrystalline $\mathrm{Sb}$ oxide were determined as $100 \%$ for $\mathrm{Sb}(5.5)-, 85 \%$ for $\mathrm{Sb}(18)-$, and $16 \%$ for $\mathrm{Sb}(55)-\mathrm{Ti}-\mathrm{O}$. These may include very small particles (below 5 $\mathrm{nm})$ of $\mathrm{Sb}_{6} \mathrm{O}_{13}$ which could not be detected by this method. The line broadening of $\mathrm{Sb}_{6} \mathrm{O}_{13}$ peaks in the catalysts was not observed. The amounts of noncrystalline $\mathrm{Sb}$ oxide determined as described above are 2.7 $\mu \mathrm{mol} \mathrm{m}^{-2}$ for $\mathrm{Sb}(5.5)-, 9.8$ for $\mathrm{Sb}(18)-$, and 10 for $\mathrm{Sb}(55)-\mathrm{Ti}-\mathrm{O}$ (Table 2). The amount of $\mathrm{Sb}$ oxide on the surface of $\mathrm{TiO}_{2}$ does not seem to increase above ca.10 $\mu \mathrm{mol}$ $\mathrm{m}^{-2}-\mathrm{TiO}_{2}$. With $\mathrm{Sb}(55)-\mathrm{Ti}$, the remaining $\mathrm{Sb}$ oxides crystallize as $\mathrm{Sb}_{6} \mathrm{O}_{13}$.

The FTIR spectra of the Sb-Ti-O catalysts are shown in Fig. 1 and their peak positions are listed in Table 2 . The spectra were obtained by subtracting the $\mathrm{TiO}_{2}$ spectra from the original spectra of the catalysts. $\mathrm{Sb}(5.5)-\mathrm{Ti}-\mathrm{O}$ has very weak bands at 900-890 $\mathrm{cm}^{-1}$. $\mathrm{Sb}(18)-\mathrm{Ti}-\mathrm{O}$ catalyst has bands at $895-870$ and $720 \mathrm{~cm}^{-1}$. $\mathrm{Sb}(55)-\mathrm{Ti}-\mathrm{O}$ has bands at 870 and $770 \mathrm{~cm}^{-1}$.
The IR bands of $\mathrm{Sb}_{6} \mathrm{O}_{13}$ were reported at $870-850,760$, and $560 \mathrm{~cm}^{-1}$ (5). Thus, the bands with $\mathrm{Sb}(18)-$ and $\mathrm{Sb}(55)-\mathrm{Ti}-\mathrm{O}$ are attributable to $\mathrm{Sb}_{6} \mathrm{O}_{13}$. Raman spectra of $\mathrm{Sb}(5.5)-$ and $\mathrm{Sb}(18)-\mathrm{Ti}-\mathrm{O}$ showed only $\mathrm{TiO}_{2}$ peaks. $\mathrm{Sb}(55)-\mathrm{Ti}-\mathrm{O}$ had a peak at 850 $\mathrm{cm}^{-1}$ due to $\mathrm{Sb}$ oxide. As has been reported by Sala and Trifiro (14), the band around 850 $\mathrm{cm}^{-1}$ is attributable to the $\mathrm{Sb}=0$ stretching vibration. $\mathrm{On} \mathrm{TiO}_{2}$, this band shifts from 870 to ca. $900 \mathrm{~cm}^{-1}$, going from $\mathrm{Sb}(55)$ to $\mathrm{Sb}(5.5)$. This indicates that the $\mathrm{Sb}$ oxide seems to be more distorted at lower $\mathrm{Sb}$ content on $\mathrm{TiO}_{2}$ compared to $\mathrm{Sb}_{6} \mathrm{O}_{13}$. This is in contrast to the case of Mo oxide on $\mathrm{ZrO}_{2}$ or $\mathrm{TiO}_{2}(9,10)$, where the bands of $\mathrm{Mo}=\mathrm{O}$ were shifted to lower wavenumber at low Mo concentration, for example, from 970 to $930 \mathrm{~cm}^{-1}$.

For analysis by Auger electron (A.e.) spectroscopy, the insulating nature of the

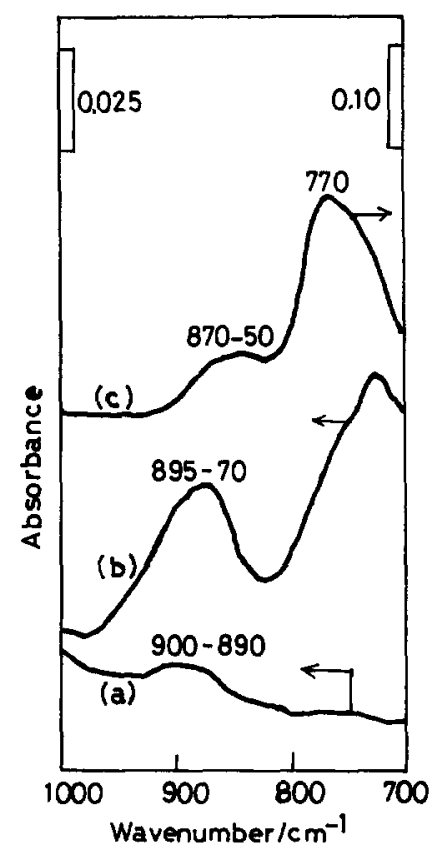

FIG. 1. FTIR spectra of SB-Ti oxide catalysts. (a) $\mathrm{Sb}(5.5)-\mathrm{Ti}-\mathrm{O}$, (b) Sb(18)-Ti-O, and (c) Sb(55)-Ti-O. Each spectra was obtained after subtraction of the $\mathrm{TiO}_{2}$ spectra. 
$\mathrm{Sb}-\mathrm{Ti}-\mathrm{O}$ catalysts made it difficult to obtain electron-excited A.e. spectra, and we resorted to the use of X-ray excitation instead. Table 2 lists the auger peak positions obtained by using $\operatorname{Mg} K \alpha$ irradiation. The kinetic energies of the $\mathrm{Sb} M_{4} \mathrm{~N}_{4,5} \mathrm{~N}_{4,5}$ peaks are $459.6 \mathrm{eV}$ for $\mathrm{Sb}_{6} \mathrm{O}_{13}, \mathrm{Sb}(18)-$, and $\mathrm{Sb}(55)-\mathrm{Ti}-\mathrm{O}$. That of $\mathrm{Sb}(5.5)-\mathrm{Ti}-\mathrm{O}$ is 460.0 $\mathrm{eV}$, which is a little higher than the other catalysts. This peak shift to higher kinetic energy value reflects an increase in the $\mathrm{Sb}^{3+} / \mathrm{Sb}^{5+}$ ratio in $\mathrm{Sb}$ oxides (15). The surface $\mathrm{Sb}$ oxide in the $\mathrm{Sb}(5.5)-\mathrm{Ti}-\mathrm{O}$ is apparently enriched with $\mathrm{Sb}^{3+}$ compared with the stoichiometric $\mathrm{Sb}_{6} \mathrm{O}_{13}$ or the other samples examined here.

As described previously (5), the $\mathrm{Sb}-\mathrm{Ti}$ oxide catalysts did not seem to have the $n$ type free electrons produced by the dissolution of $\mathrm{Sb}$ ions into $\mathrm{TiO}_{2}$ lattice because the IR transmission, i.e., background, of $\mathrm{TiO}_{2}$ did not decrease by the presence of $\mathrm{Sb}$ oxide. The highly insulating character of the catalysts for Auger measurements also seems to come from little or no presence of electrons in the conduction band. Zenkovets et al. (16) reported that some $\mathrm{Sb}$ ions are dissolved into $\mathrm{TiO}_{2}$ lattice, whose catalysts were heated at high temperature $\left(750^{\circ} \mathrm{C}\right)$.

Oxidation activity of $\mathrm{Sb}-\mathrm{Ti}$ oxide catalysts. As shown in Fig. 2, which is obtained from our previous paper (5), the $\mathrm{TiO}_{2}(\mathrm{P}-$ 25 , anatase $70 \%$ ) support itself has a high activity for the total oxidation of propene. $\mathrm{Sb}(18)-\mathrm{Ti}-\mathrm{O}$ is less active by a factor of ca. 10. But the selectivity to acrolein rises to $70 \%$ which is as high as that over $\mathrm{Sb}_{6} \mathrm{O}_{13}$. However, the activity of the $\mathrm{Sb}(18)-\mathrm{Ti}-\mathrm{O}$ catalyst is ca. 20 times higher than that of $\mathrm{Sb}_{6} \mathrm{O}_{13}$. The $\mathrm{Sb}(55)-\mathrm{Ti}-\mathrm{O}$ has a similar activity and acrolein selectivity as $\mathrm{Sb}$ (18)-Ti-O. These results indicate that the activity due to $\mathrm{TiO}_{2}$ seems to disappear above ca. 18 at $\%$ of $\mathrm{Sb}$ and that the oxidation activity mainly comes from $\mathrm{Sb}$ oxide dispersed on it.

Labeled propene oxidation on $\mathrm{S} b-\mathrm{Ti}-\mathrm{O}$ catalysts. In order to understand the rate
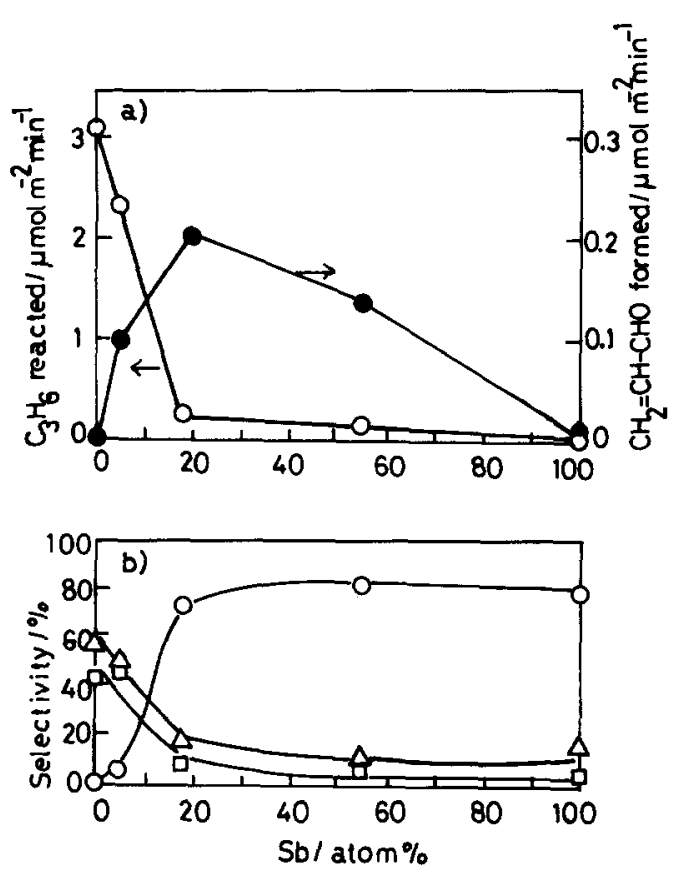

FIG. 2. (a) Rates of propene conversion over $\mathrm{Sb}-\mathrm{Ti}$ oxide catalysts as a function of $\mathrm{Sb}$ content. $P_{\mathrm{C}_{3} \mathrm{H}_{6}}=24$ Torr, $P_{\mathrm{O}_{2}}=25$ Torr, and temperature $=400^{\circ} \mathrm{C}$. (b) Product selectivities: (O) $\mathrm{CH}_{2}=\mathrm{CH}-\mathrm{CHO}$, ( $\square$ ) $\mathrm{CO}$, and $(\triangle) \mathrm{CO}_{2}$; reproduced from Ref. (5).

determining step, an equimolar mixture of $\mathrm{CH}_{2}=\mathrm{CH}-\mathrm{CH}_{3}$ and $\mathrm{CH}_{2}=\mathrm{CH}-\mathrm{CD}_{3}$ was oxidized by the catalysts. As shown in Table 3 , the ratios of $\mathrm{CH}_{2}=\mathrm{CH}-\mathrm{CHO} /\left(\mathrm{CH}_{2}=\right.$ $\mathrm{CH}-\mathrm{CDO}+\mathrm{CD}_{2}=\mathrm{CH}-\mathrm{CHO}$ ) were $1 /$ 0.58 with $\mathrm{Sb}_{6} \mathrm{O}_{13}$ and $1 / 0.47$ with the $\mathrm{Sb}$ (18)-Ti-O catalyst. Table 4 shows the result for the oxidation of ${ }^{13} \mathrm{CH}_{2}=\mathrm{CH}-\mathrm{CH}_{3}$ over $\mathrm{Sb}(18)-\mathrm{Ti}-\mathrm{O}$ catalyst. The ratio of ${ }^{13} \mathrm{CH}_{2}=$

\section{TABLE 3}

Relative Amounts of Acrolein Obtained from the Oxidation of $\mathrm{CH}_{2}=\mathrm{CH}-\mathrm{CH}_{3}$ and $\mathrm{CH}_{2}=\mathrm{CH}-\mathrm{CD}_{3}$ over Two Catalysts ${ }^{a}$

\begin{tabular}{llcc}
\hline & $\mathrm{CH}_{2}=\mathrm{CH}-\mathrm{CHO}$ & $\mathrm{CH}_{2}=\mathrm{CH}-\mathrm{CDO}$ & $\mathrm{CD}_{2}=\mathrm{CH}-\mathrm{CHO}$ \\
\hline $\mathrm{Sb}(18)-\mathrm{Ti}-\mathrm{O}$ & 1.00 & 0.23 & 0.24 \\
$\mathrm{Sb}_{6} \mathrm{O}_{13}$ & 1.00 & 0.28 & 0.30
\end{tabular}

\footnotetext{
a Experimental conditions: temperature $400^{\circ} \mathrm{C}$, propene $=15$ Torr, $\mathrm{PO}_{2}=28$ Torr, propene conversion $2.4 \%$, acrolein selectivity $71 \%$, and $\mathrm{CH}_{2}=\mathrm{CH}-\mathrm{CH}_{3}: \mathrm{CH}_{2}=\mathrm{CH}-\mathrm{CD}_{3}=1: 1$.
} 
TABLE 4

Relative Amounts of ${ }^{13} \mathrm{C}$-Acrolein from Oxidation of ${ }^{13} \mathrm{CH}_{2}=\mathrm{CH}-\mathrm{CH}_{3}$ over $\mathrm{Sb}(18)-\mathrm{Ti}-\mathrm{O}^{a}$

\begin{tabular}{cccc}
\hline & ${ }^{13} \mathrm{CH}_{2}=\mathrm{CH}-\mathrm{CHO} \mathrm{CH}_{2}=\mathrm{CH}-{ }^{13} \mathrm{CHO}$ \\
& 1.00 & 0.90
\end{tabular}

${ }^{a}$ Temperature $400^{\circ} \mathrm{C},{ }^{13} \mathrm{CH}_{2}=\mathrm{CH}-\mathrm{CH}_{3}(99 \%)=7.5$ Torr, $P_{\mathrm{O}_{2}}=30$ Torr, propene conversion $8.3 \%$, and acrolein selectivity ca. $70 \%$.

$\mathrm{CH}-\mathrm{CHO} / \mathrm{CH}_{2}=\mathrm{CH}-{ }^{13} \mathrm{CHO}$ is nearly one within experimental uncertainty, indicating that both terminal carbon atoms are oxidized with equal probability. Thus, the ratio of $\mathrm{CH}_{2}=\mathrm{CH}-\mathrm{CHO} /\left(\mathrm{CH}_{2}=\mathrm{CH}-\right.$ $\mathrm{CDO}+\mathrm{CD}_{2}=\mathrm{CH}-\mathrm{CHO}$ ) gives the initial deuterium isotope effect for acrolein formation. The initial isotope effect published previously was $1 / 0.55$ for $\mathrm{Bi}-\mathrm{Mo}$ oxide at $450^{\circ} \mathrm{C}(17), 0.48$ for $\mathrm{U}-\mathrm{Sb}$ oxide at $400^{\circ} \mathrm{C}$ (18), and 0.55 for $\mathrm{Sb}-\mathrm{Sn}$ oxide at $400^{\circ} \mathrm{C}(6)$, indicating that the allylic hydrogen abstraction is rate determining. The results for $\mathrm{Sb}$ (18)-Ti-O as well as for $\mathrm{Sb}_{6} \mathrm{O}_{13}$ also suggest that the first hydrogen abstraction step is rate determining. The amounts of $\mathrm{CH}_{2}=$ $\mathrm{CH}-\mathrm{CDO}$ and $\mathrm{CD}_{2}=\mathrm{CH}-\mathrm{CHO}$ were nearly equal and indicate that the second $H(D)$ abstraction occurs with little or no isotope effect.

In order to obtain more complete information on the second hydrogen abstraction, the oxidation of cis-CHD $=\mathrm{CD}-\mathrm{CH}_{3}$ was studied. The formation of $\pi$-allyl intermedi- ate (CHD-. $\mathrm{CD}-\mathrm{CH}_{2}$ ) should lead to four acrolein species (Table 5). The results over $\mathrm{Sb}_{6} \mathrm{O}_{13}$ and $\mathrm{Sb}(18)-\mathrm{Ti}-\mathrm{O}$ catalysts gave ratios for ACR-1,2- $d_{2}$ : ACR-2-d $d_{1}$ : ACR-trans2,3- $d_{2}:$ ACR-cis-2,3- $d_{2}=1.1-1.2: 1: 1: 1$. These species are produced at nearly equal probability; consistent with the results with $\mathrm{CH}_{2}=\mathrm{CH}-\mathrm{CD}_{3}+\mathrm{CH}_{2}=\mathrm{CH}-\mathrm{CH}_{3}$, there exist little or no isotope effects in the secondary hydrogen abstraction. A similar situation was observed in the case of unsupported $\mathrm{Rh}$ catalysts as reported by Imachi et al. (12). They have discussed reasons for this observation including one possibility which involves a less symmetric surface $\pi$ allyl intermediate (12). The results for $\mathrm{Sb}_{6} \mathrm{O}_{13}$ and $\mathrm{Sb}(18)-\mathrm{Ti}-\mathrm{O}$ are almost the same. This indicates that the reaction scheme for propene oxidation over $\mathrm{Sb}$ (18)-Ti-O is the same as that on $\mathrm{Sb}_{6} \mathrm{O}_{13}$. A small excess in the amount of ACR-1,2- $d_{2}$ appears evident. This may be due in part to the deuterium substitution at the aldehyde in ACR-1,2- $d_{2}$ and an isotope effect at this site in some subsequent oxidation of acrolein. It may also indicate that the second $\mathrm{H}$ abstraction from the CHD-end of the allyl species occurs faster than from the $\mathrm{CH}_{2}$ end. Such a special isotope effect has been observed by Amenomiya and Pottie (20) who reported that the loss of $\mathrm{H}$ and $\mathrm{D}$ from deuterated ethanes in their mass spectrometric fragmentation depends on the amount of deuterium in the ethane; i.e., the loss of $\mathrm{H}$ increases with $\mathrm{D}$ substitution.

TABLE 5

Relative Acrolein Formation Rates in the Oxidation of cis-CHD $=\mathrm{CD}-\mathrm{CH}_{3}$ over Two Catalysts ${ }^{a}$

\begin{tabular}{|c|c|c|c|c|}
\hline & 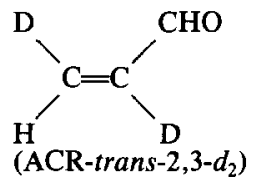 & $\underset{\left(\mathrm{ACR}-c i s-2,3-d_{2}\right)}{\mathrm{CHO}}$ & $\overbrace{\left(\mathrm{ACR}-2-d_{1}\right)}^{\mathrm{CHO}}$ & ${ }_{\left(\mathrm{ACR}-1,2-d_{2}\right)}^{\mathrm{C}=\mathrm{C}}$ \\
\hline $\begin{array}{l}\mathrm{Sb}(18)-\mathrm{Ti}-\mathrm{O} \\
\mathrm{Sb}_{6} \mathrm{O}_{13}\end{array}$ & $\begin{array}{l}1.00 \\
1.00\end{array}$ & $\begin{array}{l}1.01 \\
0.99\end{array}$ & $\begin{array}{l}0.99 \\
0.97\end{array}$ & $\begin{array}{l}1.19 \\
1.13\end{array}$ \\
\hline
\end{tabular}

${ }^{a}$ Experimental conditions: temperature $400^{\circ} \mathrm{C}$, cis- $\mathrm{CHD}=\mathrm{CD}-\mathrm{CH}_{3}(99 \%)=15 \mathrm{Torr}, \boldsymbol{P}_{\mathrm{O}_{2}}=31$ Torr, propene conversion $5 \%$, acrolein selectivity ca. $70 \%$. 
Kinetics of propene oxidation. As described above, $\mathrm{Sb}_{6} \mathrm{O}_{13}, \mathrm{Sb}(18)-$, and $\mathrm{Sb}$ (55)-Ti-O have nearly the same selectivities to acrolein and $\mathrm{CO}+\mathrm{CO}_{2}$, suggesting that the rate constants for the propene oxidation can be inferred by using a redox mechanism.

As has been proposed by a number of workers, for example, with $\mathrm{Bi}-\mathrm{Mo}$ oxides $(3,19)$, the reduction of the oxides with propene and its oxidation by gaseous oxygen occur in different regions on the surface, $A$ and $B$, respectively. The surface anion vacancies formed in region $A$ are refilled by diffusion of the oxide ions in the bulk, which results in the formation of surface anion vacancies in region $B$. These vacancies bring about the oxygen uptake. Assuming the stationary state of the oxygen flow $\left(-d[\mathrm{O}]_{\mathrm{A}} / d t\right.$ $=d[\mathrm{O}]_{\mathrm{B}} / d t$, where $[\mathrm{O}]$ denotes the surface oxygen concentration at each region), the following equation holds (21):

$$
k_{\mathrm{A}} N_{\mathrm{A}} P_{\mathrm{C}_{3} \mathrm{H}_{6}} \Theta_{\mathrm{A}}=k_{\mathrm{B}} N_{\mathrm{B}} P_{\mathrm{O}_{2}}^{1 / 2}\left(1-\Theta_{\mathrm{B}}\right),
$$

where $\Theta$ and $1-\Theta$ refer to the fraction of the surface oxygen and anion vacancies in regions $\mathrm{A}$ and $\mathrm{B}$, respectively. $N_{\mathrm{A}}$ and $N_{\mathrm{B}}$ are the maximum surface oxygen concentrations which participate in the oxidation. $k_{\mathrm{A}}$ and $k_{\mathrm{B}}$ are the rate constants for the reduction step in region $A$ and for the reoxidation step in region B, respectively. A similar situation will be applicable to the $\mathrm{Sb}-\mathrm{Ti}-\mathrm{O}$ catalysts. There appears to be no marked difference between values of $\Theta_{A}$ and $\Theta_{B}(\simeq \Theta)$, if the diffusion of the oxide ions from region $B$ to $A$ is very rapid as compared to the surface reduction. Accordingly, the above equation is transformed as

$$
k_{1} P_{\mathrm{C}_{3} \mathrm{H}_{6}} \Theta=k_{2} P_{\mathrm{O}_{2}}^{1 / 2}(1-\Theta) \text {, }
$$

where $k_{1}\left(=k_{\mathrm{A}} N_{\mathrm{A}}\right)$ is the rate constant for the reduction step and $k_{2}\left(=k_{\mathrm{B}} N_{\mathrm{B}}\right)$ for the reoxidation step. The following rate equation results, which is similar to that from a simple redox model:

$$
R=k_{1} k_{2} P_{\mathrm{C}_{3} \mathrm{H}_{6}} \mathrm{P}_{\mathrm{O}_{2}}^{1 / 2} /\left(k_{1} P_{\mathrm{C}_{3} \mathrm{H}_{6}}+k_{2} P_{\mathrm{O}_{2}}^{1 / 2}\right) .
$$

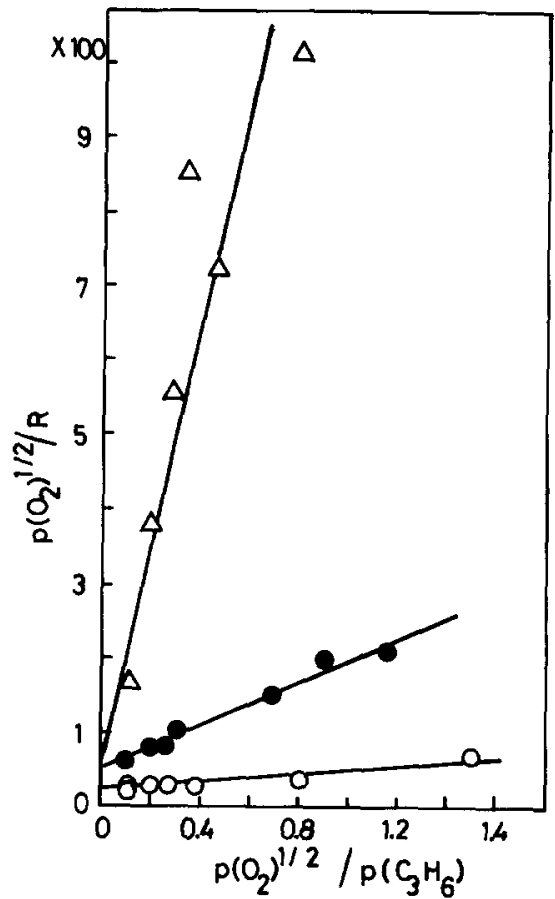

FIG. 3. Plots of $P_{\mathrm{O}_{2}}^{1 / 2} / R$ vs $P_{\mathrm{O}_{2}}^{1 / 2} / P_{\mathrm{C}_{3} \mathrm{H}_{6}}$ for $\mathrm{Sb}_{6} \mathrm{O}_{13}(\triangle)$, $\mathrm{Sb}(18)-\mathrm{Ti}-\mathrm{O}(\mathrm{O})$, and $\mathrm{Sb}(55)-\mathrm{Ti}-\mathrm{O}(\mathrm{O})$. The slope and intercept give $1 / k_{1}$ and $1 / k_{2}$, respectively.

Using this equation, the rate constants for the catalysts are calculated by applying the data in the range from 6 to 60 Torr of propene and oxygen (Fig. 3 and Table 6). As shown in Fig. 3, the plots lie on straight lines with each catalyst. This is consistent with Eq. (1). With $\mathrm{Sb}_{6} \mathrm{O}_{13}, k_{2} / k_{1}$ is 22 , indicating that the reduction step is rate determining.

TABLE 6

Rate Constants in the Oxidation of Propene over the Catalysts at $400^{\circ} \mathrm{C}$

\begin{tabular}{llccc}
\hline $\begin{array}{c}\text { Catalyst } \\
\text { (Sb at.\%) }\end{array}$ & \multicolumn{4}{c}{ Rate constants $^{a}$} \\
\cline { 2 - 5 } & \multicolumn{1}{c}{$k_{1}$} & \multicolumn{1}{c}{$k_{2}$} & $k_{2} / k_{1}$ \\
\hline $\mathrm{Sb}_{6} \mathrm{O}_{13}$ & $0.063 \times 10^{-2}$ & $1.4 \times 10^{-2}$ & 22 \\
$\mathrm{Sb}(18)-\mathrm{Ti}-\mathrm{O}$ & 3.1 & $\times 10^{-2}$ & $4.5 \times 10^{-2}$ & 1.5 \\
$\mathrm{Sb}(55)-\mathrm{Ti}-\mathrm{O}$ & 0.7 & $\times 10^{-2}$ & $1.8 \times 10^{-2}$ & 2.5 \\
\hline
\end{tabular}

${ }^{a}$ Calculated from the equation $R=k_{1} k_{2} P_{\mathrm{C}_{3} \mathrm{H}_{6}} P_{\mathrm{O}_{2}}^{1 / 2} /$ $\left(k_{1} P_{\mathrm{C}_{3} \mathrm{H}_{6}}+k_{2} P^{\mathrm{t} / 2} \mathrm{O}_{2}\right)$, see text; $R$ is rate in $\mu \mathrm{mol} / \mathrm{min} \mathrm{m}^{2}$ $\left(\mathrm{C}_{3} \mathrm{H}_{6}\right.$ reacted). Pressure ranges: $P_{\mathrm{C}_{3} \mathrm{H}_{6}}=6-60$ Torr and $P_{\mathrm{O}_{2}}=6-60$ Torr $(1$ Torr $=133 \mathrm{~Pa})$. 
With $\mathrm{Sb}(18)-$ and $\mathrm{Sb}(55)-\mathrm{Ti}-\mathrm{O}$ catalysts, $k_{2} / k_{1}$ values are $1-2$. This suggests that the reduction and reoxidation steps have comparable rates. Comparison between $\mathrm{Sb}_{6} \mathrm{O}_{13}$ and $\mathrm{Sb}(18)-\mathrm{Ti}-\mathrm{O}$ catalysts shows that the reduction step is promoted by a factor of 50 , while the reoxidation step is not promoted so much. If both the reduction and reoxidation sites increase on the $\mathrm{TiO}_{2}$ support, the ratio $k_{2} / k_{1}$ would not change between $\mathrm{Sb}_{6} \mathrm{O}_{13}$ and $\mathrm{Sb}(18) \mathrm{Ti}-\mathrm{O}$. However, they change significantly. As found by labeled propene studies, the isotope effect for the first hydrogen abstraction on the $\mathrm{Sb}(18)-\mathrm{Ti}-\mathrm{O}$ catalyst is a little larger than that on $\mathrm{Sb}_{6} \mathrm{O}_{13}$. Thus, there does not seem to be a large difference in the nature of first hydrogen abstraction between $\mathrm{Sb}_{6} \mathrm{O}_{13}$ and $\mathrm{Sb}(18)$, (55)-Ti-O. Therefore, the rate promotion in the reduction step seems to originate from the increase in the number of the active sites $\left(N_{\mathrm{A}}\right)$ rather than in the $k_{\mathrm{A}}$ of Eq. (1).

As reported previously, with the $\mathrm{V}-\mathrm{Ti}-\mathrm{O}$ and Mo-Ti-O catalysts (9), the reduction step $\left(k_{1}\right)$ in the propene oxidation over $\mathrm{V}$ oxide or Mo oxide dispersed on $\mathrm{TiO}_{2}$ was also enhanced, while the reoxidation step $\left(k_{2}\right)$ was not. Similar results were also obtained in the case of Mo oxide dispersed on $\mathrm{ZrO}_{2}(10)$ and $\mathrm{V}-\mathrm{Mo}$ mixed oxide catalysts (2l). The same analysis as described above would be applicable in these cases.

In the case of $\mathrm{Sb}-\mathrm{Sn}$ oxide catalysts, Volta et al. (4) have proposed that the surface $\mathrm{Sb}^{3+}-\mathrm{Sb}^{5+}$ couples produced on $\mathrm{SnO}_{2}$ into which $\mathrm{Sb}$ ions are dissolved should be responsible for partial oxidation. We have proposed $(5,6)$ that the promotion of the oxidation activity can be attributed to an increase in the reduction step due to the presence of Sn ions. With U-Sb oxide catalysts, Grasselli et al. (3) have proposed the following:

$$
\begin{gathered}
\mathrm{C}_{3} \mathrm{H}_{6} \stackrel{\mathrm{Sb}^{3+}-\mathrm{O}-\mathrm{Sb}^{5+}}{\longrightarrow} \pi \text {-allyl } \\
\pi \text {-allyl } \stackrel{\mathrm{Sb}^{5+}-\mathrm{O}-\mathrm{Sb}^{5+}}{\longrightarrow} \mathrm{CH}_{2}=\mathrm{CH}-\mathrm{CHO}
\end{gathered}
$$

They explained that the $\mathrm{Sb}^{3+}-\mathrm{O}-\mathrm{Sb}^{5+}$ and $\mathrm{Sb}^{5+}-\mathrm{O}-\mathrm{Sb}^{5+}$ moieties are responsible for $\pi$-allyl formation and oxygen insertion during acrolein formation, respectively.

In the present work, as described above, $\mathrm{Sb}$ ions do not seem to dissolve into the $\mathrm{TiO}_{2}$ lattice and the $\mathrm{Sb}(5.5)-\mathrm{Ti}-\mathrm{O}$ catalyst has a higher concentration of $\mathrm{Sb}^{3+}$ than others, but there is no strong evidence that the $\mathrm{Sb}(18)-$ and $\mathrm{Sb}(55)-\mathrm{Ti}-\mathrm{O}$ catalysts have an excess of $\mathrm{Sb}^{3+}$ on the surface. The IR, Auger, and XRD results indicate that electronic environment around $\mathrm{Sb}$ is perturbed in the low $\mathrm{Sb}$ content catalysts, perhaps suggesting that the $\mathrm{Sb}$ oxide is somewhat distorted as compared to $\mathrm{Sb}_{6} \mathrm{O}_{13}$. In that case the increase in the reduction sites might be attributed to the exposure of $\mathrm{Sb}^{3+}$ ions by the interaction with $\mathrm{TiO}_{2}$ which affects a change in coordination geometry around $\mathrm{Sb}$.

\section{ACKNOWLEDGMENTS}

The authors thank Dr. Takashi Ohno (Kobe University) for FTIR measurements, Dr. Kurt Hillig for assistance in the isotope labeling experiments, and the Rackham Graduate School at the University of Michigan for supplies and equipment funds. The microwave spectrometer was supported by a grant from the National Science Foundation, Washington, DC.

\section{REFERENCES}

1. Berry, F. J., in "Advances in Catalysis" (D. D. Eley, H. Pines, and P. B. Weisz, Eds.), Vol. 30, p. 97. Academic Press, New York, 1981.

2. Centi, G., and Trifiro F., Catal. Rev. 28, 165 (1986).

3. Grasselli, R. K., Brazdil, J. F., and Burrington, J. D., in "Proceedings, 8th International Congress on Catalysis, Berlin, 1984," Vol. V, p. 369. Dechema, Frankfurt-am-Main, 1984; Burrington, J. D., Kartisek, C. T., and Grasselli, R. K., J. Catal. 87, 363 (1984).

4. Volta, J. C., Bussiere, P., Coudurier, G., Herrmann, J. M., and Vedrine, J. C., Appl. Catal. 16, 315 (1985).

5. Ono, T., Yamanaka, T., Kubokawa, Y., and Komiyama, M., J. Catal. 109, 423 (1988).

6. Ono, T., Hillig, K. W., II, and Kuczkowski, R. L., J. Catal. 123, 236 (1990).

7. For example, Haller, G. L. and Resasco, D. E., in "Advances in Catalysis" (D. D. Eley, H. Pines, and P. B. Weisz, Eds.), Vol. 36, p. 173. Academic Press, New York, 1989. 
8. For example, Bond, G. C., Zurita, J. P., and Framerz, S., Appl. Catal. 22, 361 (1986); Miyamoto, M., Yamazaki, Y., Inomata, M., and Murakami, Y., $J$. Phys. Chem. 85, 2368, 2377 (1981); Gavani, F., Genti, G., Foresti, E., Trifiro, F., and Busca, G., J. Catal. 106, 251 (1987); Haber, J., Kozlowska, A., and Kozlowski, R., J. Catal. 102, 52 (1986); Kang, Z. C., and Bao, Q. X., Appl. Catal. 26, 251 (1986).

9. Ono, T., Nakagawa, Y., Miyata, H., and Kubokawa, Y., Bull. Chem. Soc. Japan 57, 1205 (1984).

10. Ono, T., Miyata, H., and Kubokawa, Y., J. Chem. Soc. Faraday Trans. 1 83, 1761 (1987).

11. Imachi, M., Cant, N. W., and Kuczkowski, R. L., J. Catal. 75, 404 (1982).

12. Imachi, M., Kuczkowski, R. L., Groves, J. T., and Cant, N. W., J. Catal. 82, 355 (1983).

13. Choi, H., Lin, J., and Kuczkowski, R. L., J. Catal. 99, 72 (1986).

14. Sala, F., and Trifiro, F., J. Catal. 41, 1 (1976).
15. Komiyama, M., Yoshii, M., Ogino, Y., and Ono, T., Shokubai 29, 498 (1987). [Japanese]

16. Zenkovets, G. A., Tarasova, D. V., Andrushkevich, T. V., Aleshina, G. I., Nikoro, T. A., and Ravirov, R. G., Kinet. Catal. 20, 307 (1979).

17. Adams, C. R., and Jennings, T. J., J. Catal. 3, 549 (1964).

18. Keulks, G. W., Yu, Z., and Krenzke, L. D., J. Catal. 84, 38 (1983).

19. For example, Matsuura, I., and Schuit G. C. A., J. Catal. 25, 314 (1972); Haber, J., and Grzybowska, J., J. Catal. 28, 489 (1973); Otsubo, T., Miura, H., Morikawa, Y., and Shirasaki, T., J. Catal. 36, 240 (1975); Ueda, W., Moro-Oka, Y., and Ikawa, T., J. Chem. Soc. Faraday Trans. 1 78, 495 (1982).

20. Amenomiya, Y., and Pottie, R. F., Canad. J. Chem. 46, 1741 (1968).

21. Ono, T., and Kubokawa, Y., Bull. Chem. Soc. Japan, 55, 1748 (1982). 